\title{
APROXIMACIÓN A LA FISCALIDAD SOBRE LA PESCA EN EL BARBANZA DEL ANTIGUO RÉGIMEN. EL DIEZMO DE MAR Y OTRAS CARGAS
}

\author{
Por \\ JOSÉ MANUEL VÁZQUEZ LIJO
}

\section{INTRODUCCIÓN}

El objetivo básico del presente artículo no es otro que lograr un acercamiento a la tipología y cuantía de las contribuciones que gravaban la producción pesquera a lo largo de la Edad Moderna. También tendrán cabida en estas páginas una serie de «limosnas» -a simple vista voluntarias- que mermaban, en un grado difícil de calibrar, el beneficio extraído por los pescadores del producto de sus faenas. Secundariamente, haremos mención a una renta como los quebrazos de mar que, si bien su naturaleza no es la de una carga impositiva, coartaba, por no decir impedía, el libre aprovechamiento de ciertos frutos salidos de las aguas. No obstante, la clave discursiva del presente estudio girará en torno al diezmo de mar, prestando especial atención a la conflictividad que, sobre todo desde el último tercio del siglo XVIII, originó su cobranza. El marco

\footnotetext{
' Becario predoctoral del Departamento de Historia II -área de Historia Moderna- de la Universidad de Santiago de Compostela, por la Consellería de Educación y Ordenación Universitaria de la Xunta de Galicia.
}

"CUADERNOS DE ESTUDIOS GALLEGOS", Tomo XLVI, Fascículo 111, Santiago 1999. 
geográfico privilegiado ha sido el Barbanza ${ }^{2}$, comarca de extenso litoral que en aquellas centurias contaba con un amplio sector profesional dedicado a la explotación de ingentes recursos tanto piscícolas como marisqueros, ambos de remarcada calidad. Está bien documentada la exquisitez de la sardina capturada en la ría de Noia, que en opinión del Licenciado Molina en su Descripción del Reino de Galicia (1550) «habiendo ésta no se despacha otra» ${ }^{3}$; por otra parte, en su conocida «visita» a principios del siglo XVII, Jerónimo del Hoyo consideraba a la merluza pescada por los mareantes de a Pobra do Deán como la más apreciada del Reino, una especie capturada a cordel en las aguas arosanas y requerida por los proveedores de la Real Armada ${ }^{4}$, por no hablar de la gran demanda y calidad acreditada, ya desde el Medievo, de la ostra criada en los recodos de Abanqueiro y Rianxo5. En cuanto a la cantidad de las capturas, señalemos que O Son, otro puerto barbanzano, a la altura de 1751 encabezaba de forma destacada el ranking de valores de la renta de millones sobre pesca industrializada en puertos gallegos, con $313.232 \mathrm{mrs}$. Precisamente allí se estableció en 1774, con el benepláçito de Carlos III, una pionera factoría para la salazón a gran escala de la merluza y el abadejo -«obgetos de la mayor consequencia al interes nacional»-, que resultó un éxito. Dirigido por el vasco Juan de Vildós, este establecimiento despa-

\footnotetext{
${ }^{2}$ Como estudios de amplio alcance centrados en dicho marco físico, destacamos: BRAVO CORES, D.: El Barbanza Meridional en el Antiguo Régimen. Población, sociedad y economía. (Memoria de licenciatura inédita), Univ. de Santiago de Compostela, 1978; COSTA RODIL, J.: Rianxo en el Antiguo Régimen. Economía y sociedad en una villa marítima del señorío arzobispal de Santiago. (Memoria de licenciatura inédita), Univ. de Santiago de Compostela, 1981.

${ }^{3}$ Véase, MEIJIDE PARDO, A.: <<Aspectos del comercio gallego de exportación a Portugal en el siglo XVIII>>, en Actas de las I Jornadas de Metodología Aplicada a las Ciencias Históricas, vol. III, Santiago, 1975, p. 819; PÉREZ COSTANTI, P.. Notas viejas galicianas, Tomo I, Vigo, 1925, p.112.

${ }^{4}$ HOYO, Jerónimo del,: Memorias del Arzobispado de Santiago, edic. de A. Rodríguez Gonzalez y B. Varela Jácome, Santiago, s. f., p. 174. En 1591 el concejo y vecinos del Caramiñal y de Ribeira se obligaron a entregar a un comisario de abastos de S.M. 100 y 50 quintales de la citada especie, respectivamente. Vid. PÉREZ COSTANTI, P. : op.cit., p.110.

${ }^{5}$ Véase, MEIJIDE PARDO, A.: $<<$ Notas históricas sobre ostricultura en la Ría de Arosa>>, en Cuadernos de Estudios Gallegos, tomo XXIV, n $72-74$ (1969), pp. 463 488.
}

"CUADERNOS DE ESTUDIOS GALLEGOS", Tomo XLVI, Fascículo 111, Santiago 1999. 
chaba a la altura de 1787 «hasta 3.000 quintales todos los años» ${ }^{6}$. Lógicamente esta relevancia en la cantidad, y sobre todo en el volumen de la pesca explica, como bien patente se muestra en la Tabla 1 que incluímos al final del presente trabajo, las elevadas cifras de marinería (muchachos, hombres de servicio, jubilados e inhábiles para la prestación militar) y embarcaciones del Barbanza registradas, a mediados del siglo XVIII, en las listas de la matrícula de mar, requisito indispensable para ocuparse en las distintas tareas de la navegación y de la pesca ${ }^{7}$. Una vez apuntados estos indicios acerca del indudable peso de las actividades pesqueras en el área objeto de estudio, pasamos a analizar, en la medida en que las fuentes consultadas lo permiten, la fiscalidad sobre la pesca comenzando por aquellas contribuciones que propiamente no pueden considerarse cargas impositivas.

\section{LAS LIMOSNAS}

Los mareantes veían retraídas las ganancias materiales de su pesca, ya que sus «obligaciones» espirituales les conducían a destinar parte del producto de su trabajo a limosnas. Citaremos unos cuantos ejemplos de este tipo de contribuciones piadosas satisfechas por los pescadores barbanzanos, si bien no incluiremos aquí, como es de suponer, aquellas ingresadas por cofradías fundadas por ellos, pues en el caso de estas últimas obras pías no ofrece dudas el interés del gremio de mar por el sostenimiento de tales fundaciones, una obligación que por voluntad propia ha-

${ }^{6}$ Datos aportados en MEIJIDE PARDO, A.: Economía marítima de la Galicia Cantábrica en el siglo XVIII, Valladolid, 1971, p. 147; MEIJIDE PARDO, A.: <<Hombres de negocios de La Coruña dieciochesca. Jerónimo Hijosa $>>$, en Revista (Instituto José Cornide), año III, nº 3, A Coruña (1967), pp. 136-137; Archivo-Museo Don Álvaro Bazán (El Viso del Marqués). Matrículas. Leg. 1873. Doc. Ferrol, 8-XII-1787.

Más cifras de capturas en puertos barbanzanos para la segunda mitad del siglo XVIII, en CORNIDE SAAVEDRA, J.: Memoria sobre la pesca de la sardina en la costa de Galicia, Madrid, 1774, pp. 151-152; y LABRADA, L.: Descripción económica del Reino de Galicia, Ferrol, 1804 (reed., Vigo, 1971) pp. 58-60.

${ }^{7}$ Sobre la Matrícula de mar y alguna de sus repercusines socio-económicas en el Barbanza, remitimos a nuestra tesina de próxima lectura. 
bían aceptado al aprobar sus constituciones ${ }^{8}$. Comenzando por Pobra do Deán, sabemos que en dicha parroquia había la «costumbre inmemorial» de contribuir con sus petos tanto «barcos» como «chalupas», los primeros a 8 reales cada uno y los segundos a 4 reales. Hasta 1660, en las cuentas de la fábrica no se especifica el capítulo de la «limosna de las embarcaciones», encontrándonos con contribuciones de «los secadores de la villa» de «los maestros de su serco», de «algunos volanteros», etc... Desde esa fecha constatamos que los petos aportan cantidades variables un año tras otro; así, por ejemplo en 1670 su limosna alcanza los 92 reales, numerario que se eleva hasta 134 reales en 1720 para volver a bajar a 64 reales en 1740. En el año 1790 la limosna de los barcos posibilita que las arcas parroquiales ingresen 108 reales, y finalmente en 1820 fecha en la que hemos rematado nuestro seguimiento de estas cuentas, en el cargo de dinero de la fábrica de la Puebla del Deán se anotan 92 reales aportados por las embarcaciones de la villa ${ }^{9}$. En cuanto a Rianxo, sabemos por un litigio ventilado en 1673 ante la Real Audiencia de Galicia que los mareantes de esta villa aportaban de limosna «al cura y sin cura que es o fuese de dicha villa desde el día primero de henero asta el de San Miguel de setiembre de 20 reales, uno, y desde dicho día de San Miguel al de henero de quinze, otro, por razón de la pesca...» que se capturase con los aparejos que se armaban en el campo nombrado de Nuestra Señora de la Cruz donde los mareantes disfrutaban de la «quieta y pazífica posesión» de « açer [...] las secadas, chinchorros y más xarzias de pescar engugando redes y otras cosas para aprovechamiento, útiles y convenientes...» a su oficio $^{10}$. También el convento franciscano de San Antonio del Xobre, saca-

${ }^{8}$ Vid. VÁZQUEZ LIJO, J.M.: $<$ El mundo de las devociones. Las cofradías de mareantes en el Barbanza del Antiguo Régimen $\gg$, en Compostellanum, vol. XLII, $\mathrm{n}^{\circ}$ 1-2 (1997).

${ }^{9}$ Archivo Parroquial de Santiago de a Pobra do Deán y su anexo Sta. Cruz de Lesón. Libro de Fábrica y Fundaciones (1719-1790), fol. 271 .Libro $3^{\circ}$ de Fábrica (17971850).

${ }^{10}$ Archivo del Reino de Galicia (A.R.G.). Real Audiencia de Galicia. Veciños. Leg. $8.292, \mathrm{n}^{\circ} 31$. El pleito fue movido por los mareantes contra la Justicia y Regimiento de la villa de Rianxo, acusándola de permitir la edificación de dos casas en dicho campo. La parte demandada presentó contradición a dicha «querella de fábrica y denuncia de obra nueva», esgrimiendo en su defensa que dicho territorio se incluía entre los bienes de propios de la villa, el cual «de largo a largo consina con la mar [...] y porque no hubiese 
ba partido de este «excedente devocional» de la pesca. Para mediados del siglo XVII conocemos en qué frutos se concretaba su petitorio y donde se practicaba. Así se nos informa que : «las pescadas se piden en la Puebla siempre que las cojen. La sardina también en su tiempo en la villa [posiblemente haga referencia al Caramiñal]. En Santa Eugea [Ribeira] se pide el congrio el mismo dia de la Santa». El petitorio de esta especie acabada de mencionar, ya curada, igualmente se efectuaba en Corrubedo y en Palmeira, puerto este último que también contribuía con «pulpos y todo género de pescado por el adviento» ${ }^{11}$.

\section{EL CAMBO Y LA MEDIA DIEZMA. OTROS DERECHOS}

Ahora, ocupándonos de Noia, debemos decir que el Arzobispo de Santiago, señor de dicha villa, gozaba «por virtud de real Privilegio concedido el 4 de Agosto de 1458 por S.M. el señor Don Henrique IV» de la renta conocida como cambo $^{12}$, y que se concretaba, en lo relativo al producto pesquero, en la percepción de «cada Barca [del xeito] un Millar de sardina

embarazo se plantó de Arboledo y la tempestad de dicho mar arrancó los árboles y en las crecidas se apoderó en mucha parte de dicho campo y dentro de poco tiempo con las tempestades lo anegará todo con que se entrará la mar en dicha villa y la arruynará y se quitan los caminos de a pie y de a cavallo...» Ya que dicha villa «lo más que thiene de renta son mil reales de vanastería los cuales sirven para el servicio ordinario, para la festividad del Corpus Cristi y para un censo de los racioneros de Santo Expritus, y para la cera del Juebes Santo...», la Justicia y Regimiento optó por aforar el terreno de dicho campo «que está anegado y arruynado... en el Mayor postor para fabricar dichas casas por un ducado de renta...»

${ }^{11}$ Vid. Archivo Histórico Universitario de Santiago (A.H.U.S.). Clero. Leg. 1.000. Cobrador y libro de gastos de San Antonio de La Puebla (1618-1685). Fol. 37 r. No obstante, estas solicitudes - por lo que sabemos por contabilidades de otros conventos gallegos de dicha orden, con questas litorales- no alcanzaban a cubrir la demanda de pescado de estas comunidades religiosas, que tendrían que recurrir a su compra. Sobre esta particular, consúltese, REY CASTELAO, O.: El Colegio de Misiones de Herbón y su contexto histórico a mediados del siglo XVIII, Santiago de Compostela, 1997, pp. 34-35.

${ }^{12}$ Véase, Archivo General de Simancas (A.G.S.). Secretaría de Marina. Leg. 281; doc. s.f. Noticia de los derechos que la gente de mar de varios Puertos de este reyno paga por razón del Pescado que coge o en expecie de él... El texto íntegro aparece reproducido en el apéndice documental del presente trabajo.

"CUADERNOS DE ESTUDIOS GALLEGOS", Tomo XLVI, Fascículo 111, Santiago 1999. 
fresca cabezuda, cada año, pago por el Mes de Diciembre». Además, se recaudaba «de cada traíña cinco reales y medio al año, pagos por el mes de setiembre y en el presente del 50 [año 1750] son 4 traíñas», y dicha dignidad arzobispal también percibía «por el berano, de los barcos que ban a la pesca de tramallos de cada uno tres reales». Además del cambo, este señor recaudaba en la villa de Noia la llamada media diezma. Por donación «del Rey don Fernando el $4^{\circ}$ de la era de 1342» dicha Dignidad había disfrutado de la recaudación de la media diezma en todos los puertos de su arzobispado; este privilegio fue acreditado por reales cédulas e informaciones de los años 1606 y 1709 «y se continuó su cobranza hasta el año de 1716, en el que con el motivo de las Aduanas, S.M. incorporó estas medias diezmas a la Real Hazienda; las cuales consistían y se reducían a lo que se descargaba de puertos extrangeros y cargaba de los del Reino para fuera de él. La otra mitad de diezmas ya la tenía el Rey. Acudiose por parte de la Dignidad al Consejo y ante S.M., quien [...] en el año de 1752, resolvió y mandó que desde entonces, y a lo adelante se pague a la Dignidad en recompensa de este derecho al respecto de 9.604 reales vellón al año sobre el producto de las Rentas Generales» ${ }^{13}$.

Los mareantes de Noia, por otro lado veían cargadas sus capturas por el concejo de la villa, ya que por privilegio real de 1737, la justicia y regimiento de ella recaudaba 4 mrs. de cada millar de sardina «para atender con su producto a los precisos reparos de la Yglesia Parrochial, Fuente y Puente» ${ }^{14}$. Por R.O. de 23 de diciembre de 1782 se concedía libertad

${ }^{13}$ Archivo Histórico Diocesano de Santiago (A.H.D.S.). Fondo General, Leg. 76. Dicha carpeta contiene rica información sobre ambos derechos que cobraba el Arzobispo de Santiago en los puertos de mar sitos en el territorio sobre el cual ejercía la máxima autoridad religiosa. En la Alta Edad Media, este impuesto le reportaba elevados beneficios en puertos de importante tráfico, caso de Pontevedra. En 1321, precisamente allí, el cabildo compostelano adquiere un censo de 2.500 morabetinos, situado sobre las diezmas de mar de dicha villa. Vid. BARREIRO SOMOZA, J.: $<<$ As Rías Baixas galegas nos séculos IX-XIII: economía e sociedade >>, en Actas del Coloquio de Etnografía Marítima, Santiago, 1984, p. 249.

Indicios documentales apuntan a que el arzobispo compostelano continuaba con la percepción de las medias diezmas a la altura de 1775 ; por contra, en esas mismas fechas no disfrutaría de los cambos. A.H.D.S. Fondo General. Leg. 44. Bienes y rentas de la Mitra de Santiago y pensiones que paga. Año 1775. Sin foliar.

${ }^{14}$ Véase, nota 12.

"CUADERNOS DE ESTUdios GALLEGOS", Tomo XLVI, Fascículo 111, Santiago 1999. 
absoluta «a los Pescados y Pesquerías de el Reyno de toda clase de arbitrios y demás gabelas municipales, que se exigían en las ciudades o puertos...», si bien indicios apuntan a que tal normativa no siempre se aplicó escrupulosamente; quizás prueba de ello, lo constituya la redacción de una nueva ley similar, en concreto el artículo $7^{\circ}$ del título V de la Ordenanza de Matrículas de 12 de agosto de 1802, donde se exponía que «en ninguna parte podrán los Ayuntamientos ni otras alguna Jurisdicción establecer impuestos sobre el producto de la pesca de los vasallos, sin expresa orden del Sr. Generalísimo de la Armada [Godoy], precedida consulta que en el particular haga a S.M. ...» ${ }^{15}$

Volviendo a los cambos, a la altura de 1753, el Arzobispo de Santiago no estaba en posesión de percibir por dicho concepto «tanto como en lo antiguo, como ni tampoco lo haze en todos los puertos y sólo cobra en Redondela y Noia». Obligada dicha Dignidad a acreditar documentalmente, ante la Intendencia de Marina de Ferrol, el derecho a la percepción de tales cargas, su escribanía de rentas envió al Subdelegado de Marina de Noia copia de tres privilegios reales custodiados en el Archivo Catedralicio de Santiago ${ }^{16}$. Además de dichos papeles presentó la declara-

\footnotetext{
${ }^{15}$ De similar privilegio era acreedora la junta municipal de Vigo, gracias a una real cédula de 19-XII-1703, aunque en esta información se especifica que se gravaba la sardina salada que salía de la citada villa por mar o tierra. Tal contribución podía recaudarse «hasta el completo de veinte mil ducados, con la claúsula de que así que se completasen, no se exigiese más cantidad, y la obligación de dar las cuentas anualmente al Tribunal de este Reyno». Lo percibido por tal concepto era destinado a igual fin que en el caso noies. Posiblemente a instancia de los matriculados de Vigo, la Intendencia de Marina había decretado en 1774 el cese de tal impuesto, ya que la municipalidad no pudo aportar documentación que validase la continuación de tal privilegio. Dicha prohibición sería ratificada por don Joaquín de Maguna, a la sazón máxima autoridad del departamento ferrolano, en 1779, matizándose que sí debían satisfacer tal carga aquellos que comprasen la sardina para luego comerciarla, lo que practicaban los fomentadores catalanes. Véase, Museo de Pontevedra. Archivo de mareantes. Sampedro, 315 ; docs. Pontevedra, 4-X-1774 y Ferrol, 10-II-1779.

${ }^{16}$ Entre los papeles que se adjuntan en dicha información sobre los cambos de Noia, nos encontramos con una copia de una carta de juro de heredad otorgada por Felipe II el 13 de abril de 1585 y por la cual se concedían $61.495 \mathrm{mrs}$. anuales -«situados» en la alcabala de la carne y el vino de la ciudad de Santiago- a la Dignidad arzobispal compostelana por haber «dismembrado» e incorporado a la Real Hacienda «por algunos años a la villa de Noia y su Partido [a excepción de San Félix de Riosieira] con todas sus rentas y derechos» en virtud de breve apostólico de Gregorio XIII, ganado el 6 de abril de 1574.
} 
ción de varios mareantes noieses ante el Procurador General de la villa, entre ellos, la de Juan Antonio Méndez quien reconoció los referidos derechos sobre el pescado, añadiendo que «en defecto de que así no se le entreguen el millar de sardinas cabezudas frescas, en especie, se le pagan despues al mismo respecto que la venden curada...» Otro matriculado, Bautista Conde, afirmó que dichas cargas «aún las pagó por sí mismo antes de aora, por haver andado antes de la Matrícula a la mar, como también averlo oydo a sus Padres y otros maiores que aseguraban averse echo y pagado a sus tiempos, todo sin contradizción alguna». Desconocemos si la dignidad arzobispal de Santiago continuó percibiendo tales cambos en Noia, pero resulta significativo que a la altura de mediados del siglo XVIII la Secretaría de Marina comenzase a comprobar la fundamentación de los derechos de los distintos señores sobre el producto de la pesca; así, el artículo 123 de las Ordenanzas Generales de Marina de 1748 disponía que las autoridades competentes informasen «del origen de diezmar el pescado» e igualmente se enterasen de los demás derechos ${ }^{17}$. Sin duda velando por los intereses de los matriculados, intentaban contentar a una mano de obra militar

Para fijar la «recompensa», el valor del juro, la Hacienda Real calculó el monto de todas las percepciones del Arzobispo de Santiago durante los últimos 5 años (1580-84) para establecer la media anual. Sobre el servicio de Cambo de la referida villa, se nos dice que «cada barca que va a pescar sardinas a la mar, al Jeito, un millar de sardinas y cada Pescador tramallero que va a pescar de ocho a ocho días, paga un cambo que son tres pezes, y de las sacadas pequeñas otro cambo que son 6 pescados, y éstas cada vez que va a pescar al mar y traen pescado y de cada Barco forastero una pescada y trayéndola, y de cada Barco de pesca a la línea un congrio y de las sacadas pequeñas si traen jarda de cada ciento una, que pareció aver valido en los dichos cinco años...» $44.715 \mathrm{mrs}$., lo que supone una media anual de $8.943 \mathrm{mrs}$., el 14,5\% del total de ingresos -calculados extremadamente a la baja por los funcionarios reales, para ahorrarle pagos a la Real Hacienda-, que percibiría cada año la Dignidad arzobispal de Santiago en la jurisdicción de Noia. Tambien se nos informa que la referida media diezma de dicha villa se cobra «de las mercadurías que vienen y van a fuera del Reyno y de las que pasan por el Puerto de Santa Ugía [Ribeira] porque la otra mitad pertenece a nos [el Rey] y valió al dicho Arzobispo...» 6.179 mrs., en los referidos últimos 5 años.

Por privilegio real de Felipe IV con fecha 25-II-1636, la villa de Noia y su partido dejaba de pertenecer al.Patrimonio Real siendo devuelta al Arzobispo de Santiago la jurisdicción sobre dichas tierras, «el derecho que yo [el Rey] tuviere en ella que no esté enajenado». Véase, A.H.D.S. Fondo General. Leg.76, fols.98 y ss.

${ }^{17}$ A.G.S. Secretaría de Marina. Leg. 300. Doc. Esteiro, 21-IX-1771.

"CUADERNOS DE ESTUDIOS GALLEGOS", Tomo XLVI, Fascículo 111, Santiago 1999. 
imprescindible que aborrecía, con sobrada justificación, el servicio a S.M. en los navíos ${ }^{18}$.

Como complemento a las noticias que llevamos recopilando acerca de los derechos sobre la pesca percibidos por el arzobispo de Santiago, digamos que tal señor venía disfrutando desde antiguo de una gabela sobre ciertas capturas fluviales, prácticas que continuaron siendo libres tras el establecimiento de la Matrícula. En concreto, percibía la renta de las lampreas, al ser poseedora de unos «canales» en el Tambre «junto al puente de don Alonso, Jurisdición de Noya» donde se capturaba esta especie; dicha renta solía arrendarse anualmente en 250 lampreas «de las quales ha de dar el arrendador las que se le pidiesen frescas y las restantes frescas y curadas en el tiempo y sazón de ellas, y por lo que faltare ha de dar medio Real $»^{19}$. Hemos tomado la licencia de reseñar aquí el asunto de los bienes mostrencos, y en particular de aquellos que quedaban varados en las orillas y playas de su jurisdicción, cuya propiedad se atribuía la máxima dignidad del cabildo compostelano. Si bien no se aplicaba sobre las capturas, este privilegio sí tenía implicaciones sobre especies marinas, como los cetáceos, susceptibles de diversos aprovechamientos. Así se ex-

${ }^{18}$ A.H.D.S. Fondo General. Leg. 44. Bienes y rentas... En la información sobre cambos nos encontramos con una copia del capítulo 124 de una ordenanza de Marina, de fecha desconocida ¿1748?, en la que se disponía que «si en algunas partes hubiese establecida la costumbre de contribuir a comunidades o Particulares alguna gavela en dinero, o en especie de pescado, bien sea por la lizencia de pescar o del producto de la pesca, los Ministros averiguarán los fundamentos en que estrive, y por medio de su Yntendente me informarán extensivamente de todo, mandando que desde luego cese la exsacción de las referidas contribuciones hasta que bien examinadas mande yo restablecerlas, si pareciesen justas. Porque es mi voluntad que a los pescadores no se grave ni ziña en modo alguno, sino al contrario se alivie y fomente cuanto fuere posible...». Varias décadas más tarde, las autoridades de Marina interrogarán sobre «el origen y motivo de contribuir los diezmos de pesca la Marinería, desde qué tiempo y en qué forma los pagan, a quánto asciende su valor regulado por un quinquenio...», prueba posiblemente del incremento de las críticas de los pagadores de tal carga. Véase, Museo de Pontevedra. Archivo de mareantes. Sampedro, 315. Doc. Vigo, 20 de julio de 1787.

En un reciente artículo nos hemos acercado al molestar provocado por la Matrícula y las obligaciones militares que traía pareja. Vid. VÁZQUEZ LIJO, J. M.: $<<$ Los privilegios de la Matrícula de Mar y su cuestionamiento práctico. La dureza del Real Servicio en la Armada en el siglo XVIII >>, en Obradoiro de Historia Moderna, $\mathrm{n}^{\circ} 6$ (1997). En prensa.

${ }^{19}$ A.H.D.S. Fondo General. Leg. 44. Bienes y rentas...

"CUADERNOS DE ESTUDIOS GALLEGOS", Tomo XLVI, Fascículo 111, Santiago 1999. 
plica que la posesión sobre estos quebrazos de mar provocase multitud de pleitos a lo largo del Antiguo Régimen que enfrentaron a la citada dignidad con vecinos de las poblaciones litorales, los cuales defendían su facultad para apoderarse de los peces y objetos fruto de naufragios ${ }^{20}$. Para el Barbanza sabemos de un litigio dirimido ante la Real Audiencia de Galicia y que enfrentó en 1577 a vecinos de las feligresías de Olveira, Oleiros, Artes y Carreira contra el arzobispo compostelano a raíz del aprovechamiento de una ballena que había salido a la costa. El procurador de los citados vecinos argumentaba -apoyándose en las declaraciones de los testigos de su parte-que sus representados gozaban desde tiempo inmemorial de la «quieta y pacífica posesión [...] de llevar para sus casas cualquiera pescado de qualquier calidad que sea, ansí ballenas como lubrigantes como otros qualesquiera...» que saliesen a tierra, por las tempestades o por cualquier otra causa. Afirmaba que tal hacían «en vista, haz y paz de los jueces y alcaldes y alguaciles y más personas de la villa de Noia que lo an visto y nunca lo an contradicho, antes lo aprovaron y dieron por bueno» ${ }^{21}$. La parte contraria abogaba por el privilegio del señor arzobispo a la hora de aprovecharse de «qualesquiera quiebras de naos, nabíos y lanças y duelas e pipas y baricas (sic)...» que el mal tiempo arrojaba a la costa. Entre dichos quebrazos se incluía el citado mamífero marino, al ser de gran tamaño y respetable valor, si bien a la hora de estimar esto último un testigo

\footnotetext{
${ }^{20}$ Abundante documentación referida a causas judiciales sobre este motivo en Archivo Catedralicio de Santiago (A.C.S.) Mostrencos, s. XVII (?) Leg. A; s. XVIII, Legs. A, B y C. Lamentablemente en tales carpetas no se custodia ningún expediente sobre quebrazos de mar perteneciente a la comarca que nos ocupa. Para los siglos XVI y XVII consúltese, A.H.D.S. Fondo General. Leg. 1.241.

${ }^{21}$ Toda la información referida a este pleito ha sido extraída de CABEZA DE LEÓN, S.: $<<$ Notas de un preito antre os veciños de varias freiguesías da xurisdicción de Noia e o Arcebispe de Sant-Yago, sobre o aproveitamento de unha balea botada pol-o mar, 1577>>, en Arquivos do Seminario de Estudios Galegos, (sección de Historia), V, 1930. En la costa más agreste de la comarca, a la altura de Corrubedo uno de los testigos, Ruí Pallón, labrador, en torno a los 60 años de edad, declaró que en su vida recordaba haber visto 7 u 8 ballenas varadas muertas. Cuando los peces que arrojaba el mar eran de escaso valor (congrios, pescadas, abadejos...) o venían ya en mal estado para su consumo, la propiedad sobre los mismos no resultaba problemática. Así, 6 meses antes del inicio del pleito que nos ocupa, otra ballena -llamada por algún testigo «alifante»-había salido a la costa de Carreira, pero como «venía ya hedionda» el juez de la villa de Noia permitiera el aprovechamiento de la misma por parte de los vasallos de su señor.
}

"CUADERNOS DE ESTUDIOS GALLEGOS", Tomo XLVI, Fascículo 111, Santiago 1999. 
hable de 300 ducados mientras otro reduce la tasación a 50 de la misma moneda $^{22}$. Es muy probable que los mareantes del Barbanza en los siglos venideros volviesen a tener algún que otro conflicto con la Dignidad arzobispal por el aprovechamiento de animales u otros bienes que llegaban sin dueño a sus costas. No obstante, desde el siglo XIX los señores jurisdiccionales parece ser que no pusieron en práctica con tanta rigurosidad su atribuída posesión sobre los mostrencos. Para finalizar con esta cuestión, y a modo de curiosidad, señalemos que el 1 de junio de 1809, en la ensenada de Balieiros (Corrubedo) «embistió con furia hasta barar en la arena una Ballena sin barbas, arrojando con abundancia sangre del costado por una herida bien penetrante del tamaño y figura del escobén del cable de un Navío a línea, la que espiró a pocas horas en la orilla mar. Los Marineros de aquel Puerto y sus familias de ambos sexos, se subieron sobre ella hasta un número de unas 50 personas, extrayéndole la grasa y esperma que mezclaron porque no se ciñeron al modo de preparar la segunda para velas, por ignorancia: su largo era de 35 1/2 Pies de Burgos y 12 de ancho; se infiere hubiera sido tal vez acometida y herida por algún Pege espada u otro Pez marino devorador de armazón a la semejanza del hueso espada de éste» ${ }^{23}$.

Por otra parte, el comercio de pescado de la villa de Rianxo se veía gravado por el llamado ramo de la banastería, propiedad de dicha villa desde que en 1617 Felipe III se lo había adjudicado por la cantidad de $36.000 \mathrm{mrs}$. mediante el sistema de la venalidad en la concesión de los oficios. Este impuesto municipal era arrendado en subasta pública cada año a principios de enero; quien se quedaba con la postura, debía prestar fianza, y tras ello, pasaba a disfrutar del derecho a cobrar «por cada par de banastas que daba [el arrendatario] para la saca del pescado 3 reales vellón. Sino la da el arrendatario del ramo, éste recibirá 1,5 reales por cada par de banastas de pescado que se saque $»^{24}$. Dicho ramo no fue suprimido

${ }^{22}$ Ibidem. Según el estudioso del pleito que nos ocupa, éste no debió pasar de su parte testifical, ya que no aparecen más diligencias en el expediente, lo que posiblemente obedezca tanto a la desaparición del objeto del litigio como a los escasos resultados de las pesquisas efectuadas por los jueces elegidos por la Mitra.

${ }^{23}$ Museo Naval (Madrid). Noticias Hidrográficas. Doc. $\mathrm{n}^{\circ} 1$.

${ }^{24}$ Sabemos que «la banasta es la gran cesta que sirve para que el pescado de la villa salga en esos recipientes a lomos de caballerías...» pero bajo esa misma denominación tambien se conoce «la unidad de medida de la exportación de pescado dado que los 
hasta después de 1820, a pesar de la mencionada Real Orden de 23 de diciembre de $1782^{25}$.

Las economías pesqueras que también se veían fiscalizadas por la aplicación de otros derechos señoriales, tales como ciertos privilegios disfrutados por comunidades religiosas y consistentes en su prioridad a la hora de abastecerse de pescado curado en la cuantía que fuera preciso para su alimentación, antes de ser vendido en el mercado ${ }^{26}$. Por otra parte, el libre comercio de la producción pesquera se vió entorpecido por la actuación de las autoridades municipales. Así, en 1750, el diligente ministro de Marina de la provincia de Pontevedra, don Francisco Javier García Sarmiento, hermano del erudito benedictino, entre sus propuestas para fomentar las pesquerías y la matriculación incluía tomar providencia en el tráfico de pescado «tierra a dentro, porque se padecen muchas extorsiones de los Regidores, que no permitiendo que se venda sin postura, lleban por este título las mejores piezas de las banastas, con que imposibilitan el comercio en perjuicio del público» ${ }^{27}$. En otro orden de cosas, conviene apuntar que en las contabilidades de cofradías religiosas y fábricas parroquiales del litoral barbanzano abundaban los ingresos procedentes de sanciones por faenar en días vedados. Así en la visita de 1576 realizada por el canónigo compostelano don Cristóbal Colón a la feligresía de la villa de Noia, se ordenaba al vicario de San Nicolás que castigase a los que mareaban en domingo o días festivos, transgresión corriente en todas las Rías Bajas ${ }^{28}$, y que continuó en el siglo venidero, mientras que

impuestos se realizan [...] efectuando su pago por cada par de banastas que se da para la saca del pescado». COSTA RODIL, J.: op. cit., pp.59 y ss. El autor, de la lectura de la concesión real de dicho oficio deduce que «1,5 rs. estaban destinados al pago de las dos banastas, y los otros 1,5 por el pescado que salía en ese par de banastas...».

${ }^{25}$ Ibidem.

${ }^{26}$ RODRÍGUEZ GALDO, $\mathrm{M}^{\mathrm{a}}$. J.: $<<$ Nos alicerces do subdesenrolo galego: a pesca a mediados do século XVIII >>, en Grial, tomo XV, n56 (abril-junio de 1977), p. 171.

${ }^{27}$ A.G.S. Secretaría de Marina. Leg. 378. Doc. 13-II-1750.

${ }^{28}$ Archivo Parroquial de San Martín de Noia. Visita de 1576.

Para el Morrazo, véase, RODRÍGUEZ FERREIRO, H.: Economía y población rural en la Galicia Atlántica. La jurisdicción del Morrazo en los siglos XVII y XVIII. (Tesis doctoral inédita). Univ. de Santiago de Compostela, 1982, vol. 3, p. 215. En la colección Sampedro abunda documentación, sobre todo del siglo XVI, relativa a la imposición de pignoras a los pescadores de la Moureira por faenar en días festivos. Sin ánimo de exhaustividad citamos las carpetas 37 y 295. También sobre este particular, en el mismo Archivo de mareantes, consúltese, Gremio, 31.

"CUADERNOS DE ESTUDIOS GALLEGOS", Tomo XLVI, Fascículo 111, Santiago 1999. 
-a juzgar por la falta de ingresos a raíz de multas por tal delito, llamadas penoras - no se cometería con tanta asiduidad en el siglo XVIII; si bien cabe otra hipótesis: que su no registro se deba al incumplimiento de las sanciones pecuniarias ${ }^{29}$, penas a las que en ocasiones se añadía la privación de libertad ${ }^{30}$. Conviene apuntar que la Ordenanza de Pesca de la provincia de Pontevedra del año 1768 seguía prohibiendo expresamente tales prácticas. En concreto en su artículo 39 se disponía que «ningún matriculado pueda exercitarse en la pesca en los Domingos y Días de Fiesta reser-

${ }^{29}$ Así, en la visita de 1684 realizada a la parroquia de Santiago de la Puebla del Deán leemos lo siguiente: «Por quanto su merced halló por el libro antiguo de dicha fábrica que cada barco de dicha villa que andan a la pescada pagan cada uno ocho reales por razón de algún día de fiesta que se quedan en la mar, lo cual no quieren hacer ni pagar lo que tan justamente deben, mande su merced se les notifique dentro de seis días, pague cada uno los años que estubieren deviendo pena de excomunión maior». En las cuentas de 1640 , se ingresan 280 reales por «quebrantamientos de fiestas» por parte de los mareantes. Véase, A.P. Santiago del Deán y su anexo Santa Cruz de Lesón. Libro de Fundaciones y Visitas (1676-1733), fol. 42 r.; Libro de Visitas y Fábrica (16301671). En cuanto a Palmeira, sabemos por las cuentas de los años 1611-1613 que 71 rs. del total del cargo de la fábrica (502 rs.) se sitúan en el apartado de «condenaciones» por faenar en días vedados. La misma fuente nos informa del número de infractores, 15; 13 son multados con 4 rs., uno recibe el doble de sanción pecuniria, mientras cierra la lista un pescador que debió satisfacer un real. Vid. A.H.D.S. Fondo Parroquial de San Pedro de Palmeira. Libro ${ }^{\circ} 1$ de Administración Parroquial. Fábrica (1606-1707).

La sexta de las constituciones antiguas del Santísimo Sacramento del Caramiñal, aprobadas en 1618, disponía «que los mayordomos que fueren, ayan de ir y vayan a la mar como es de costumbre, aprendan los que en esta Ría quebrantaren las fiestas mareando en ellos, sin que persona alguna les ponga en ello impedimento, ni estorbo alguno, y lo que así cobraren asienten en el dicho libro para que se gaste y distribuya en servicio de la dicha cofradía con pareçer del dicho Rector y cofrades». A. P. Caramiñal. Libro $2^{\circ} d e$ la cofradía del Santísimo Sacramento (1753-1877).

${ }^{30}$ Por denuncia formulada por el abad de Coruxo, subdelegación de Vigo, ante el Ministro de Marina, tres matriculados de dicha feligresía sufrieron «3 días de cárzel» por pescar con dorna en días prohibidos. Véase, Museo de Pontevedra, Archivo de mareantes, Sampedro 249. Doc., Pontevedra, 10-VIII-1772.

Además, tenemos testimonios de acusaciones ante el ministerio de Marina sobre la escasa diligencia de los cabos celadores y procuradores de ciertos puertos (caso de Lourizán, Canto de la Arena, o de la propia villa de Pontevedra) a la hora de castigar a los que faenasen en los citados días; e incluso se informa de que «como siempre hai retrasos en pagar la pena, para que no suceda, los Cabos Zeladores por de contado le sacarán prenda». Museo de Pontevedra. Archivo de mareantes. Sampedro 52. Doc. Pontevedra, Canto de la Arena, 10 de septiembre de 1772.

"CUADERNOS DE ESTUDIOS GALLEGOS", Tomo XLVI, Fascículo 111, Santiago 1999. 
vados desde que en su víspera se oculte el sol hasta que pasado el día festivo no buelba a salir por la Mañana, con imposición de peñora o Multa a los que a ello contravengan ${ }^{31}$.

\section{EL DIEZMO DE MAR Y LA TENDENCIA A SU IMPAGO}

La principal contribución específica que debían satisfacer los mareantes no era otra que el llamado diezmo de la mar, imposición eclesiástica originaria de época medieval ${ }^{32}$. Comenzando nuestro recorrido por la geografía barbanzana, hay noticia de que «a mediado del siglo de 1500» la dignidad arzobispal de Santiago percibía en el mayordomazgo de Palmeira, «ocho o nuebe dozenas» de pulpos en pago a tal derecho ${ }^{33}$. Por otra parte, sabemos que a las rentas percibidas por la fábrica de la Puebla del Deán correspondientes al año 1547, los pescadores de dicha villa contribuían con $1.500 \mathrm{mrs}$. de «diezmos de polbos [pulpos]» ${ }^{34}$; mientras, pocos años antes, en 1538, en Santa Uxía de Ribeira «los mareantes pescadores pagan por abenencia y diezmo personal, porque no pagan diezmos de otros pescados sino de pulpos, 3 reales cada uno» ${ }^{35}$. A finales del siglo XVI, concretamente en 1594, diferentes vecinos de Rianxo declaran que en cada uno de los últimos cinco años dicho tributo había reportado a la fábrica de Santa Columba hasta 30 millares de sardina «que se venden comúnmente cada myllar a 6 reales [...] y esto dende el mes de setiembre asta el fin del ano, que esto se paga en sardina, porque en la dicha villa no se pesca otro pescado ninguno [...] y que es verdad que en el berano dende el mes de mayo asta en todo el mes de setiembre se paga el diezmo de

\footnotetext{
${ }^{31}$ Ibidem.

${ }^{32}$ Se ha citado una Real Cédula del rey Juan II de Castilla, expedida en 1408, y por la cual la pesca efectuada en los puertos del arzobispado de Santiago, estaría exenta de la contribución eclesiástica que nos ocupa. No obstante, como a continuación se indicará, las fuentes documentales manejadas apuntan a que esta gracia real no se aplicaría en el siglo XVI y siguientes. Vid. LABRADA, L.: Descripción..., p. 252.

${ }^{33}$ A.H.D.S. Fondo General. Leg. 44. Bienes y rentas... Al curato de la citada feligresía le correspondía la mitad de dicho diezmo de mar. Véase, A.H.D.S. Fondo general. Leg. 257 ; doc. Palmeira, 10 de mayo de 1806.

${ }^{34}$ A.C.S. Información de beneficios. Año 1547. Fol. 139.

${ }^{35}$ Véase, BRAVO CORES, D.: op. cit., p.111.
} 
la sardina en dinero asta quatroçientos reales un año con otro, porque un año a más sardina y otro a menos y estos dos años hubo poca sardina» ${ }^{36}$.

Para principios del siglo XVII, contamos con la información del referido cardenal del Hoyo, según la cual los mareantes del Xobre pagarían 100 reales aproximadamente, en concepto de diezmo del los pulpos, impuesto que también satisfacían los pescadores de Pobra do Deán, Palmeira y Ribeira ${ }^{37}$. Volviendo a la parroquial de Santiago de A Pobra do Deán, además de las limosnas referidas en páginas precedentes, dicho beneficio eclesiástico ingresaba «los diezmos personales de la mar» que casi siempre figuran englobados en el total del ingreso decimal que se completaba con la contribución de los habitantes del «Casco de la villa» y con los vecinos de la «Aldea», obligados a satisfacer los llamados diezmos prediales. Sabemos que el principal tributario de dicha carga eran los mareantes $^{38}$; en copia de un testamento de don Carlos San Mamed, canónigo del cabildo de Santiago y administrador del Hospital de San Roque de dicha ciudad, se declara que el testador había sido «algunas años [concretamente entre 1725 y1751] cura Parrocho en dicha villa de la Puebla donde se pagan diezmos personales pero tan defectuosamente que exceptuando los marineros, los más faltan a su devida obligación...» Así, no es de extrañar que, por ejemplo, de los 168 reales y 2 mrs. percibidos por este concepto en el año 1747, los pescadores contribuyeron con 100 reales, mientras el resto fue aportado por el gremio de tierra. Desde 1795 en adelante, los diezmos personales se fijan en 96 reales, cantidad que creemos sólo fue satisfecha por los mareantes hasta 1828 , ya que en dichas

${ }^{36}$ A.C.S. Memorial de los gastos y cargas que paga la dicha Iglesia y el Rector cada año en el dicho beneficio de Rianjo... Año 1594. A dichos ingresos pagados en «invierno» por los chinchorros (secadas) y en el «verano» por los xeiteiros, había que descontar el salario de «dos o tres mujeres moças de servicio en el invierno para coger de barco en barco la sardina y pescaría y para la escoger, lavar, cobrar y recoger y poner en las pilas». Asimismo, había que pagar a uno o dos hombres encargados de ir a la compra de la sal a Villagarcía, Cambados o la Puebla del Deán. Además «da de comer el Rector, a los maestros pescadores y los geiteiros quando le vienen a entregar los petos y diezmos, da una docena de ducados en la comida y bebida de pan, trigo, carnero y baca y bino blanco como lo han tenido y tienen de uso y costumbre antiquísimo en los diezmos de la mar».

${ }^{37}$ HOYO, Jerónimo del : Memorias..., pp. 173,174 y 177.

${ }^{38}$ Archivo Parroquial de Santiago de A Pobra do Deán y su anexo Sta. Cruz de Lesón. Libro de Fábrica y Fundaciones (1719-1790), fol. 271.

"CUADERNOS DE ESTUDIOS GALLEGOS", Tomo XLVI, Fascículo 111, Santiago 1999. 
cuentas leemos que en ellas no se cargaron «los noventa y seis reales que percive la fábrica por razón de Diezmos de la mar, ni del importe de las lanchas que cada una paga a dicha fábrica por hallarse entorpecido» ${ }^{39}$. Retomaremos luego la cuestión de la resistencia al pago del diezmo.

Antes de continuar adelante conviene hacer hincapié en la falta de un capítulo específico sobre el diezmo de mar en las contabilidades de las parroquiales barbanzanas por nosotros consultadas, lo que obedece, sin duda a que la fábrica de las mismas no tenía derecho a sustentar los gastos del culto con esta contribución. Por lo tanto, hay que descartar que dicha ausencia de información pueda atribuirse al impago del diezmo o a su escasa relevancia pues es bien sabido que en el cargo de las fábricas se anota, o debiera anotarse hasta el último maravedí. Por otra parte, en las visitas no encontramos mención alguna a irregularidades en la gestión de las feligresías. Con lo que si nos encontramos en estas contabilidades son con capítulos de limosnas o petitorios de determinados pescados ${ }^{40}$. Esta penuria de datos no se repara con las contestaciones a la pregunta decimoquinta del Interrogatorio del Catastro ensenadista, pues los representantes de las parroquias que nos ocupan no reseñan información significativa alguna sobre el diezmo del pescado, con la única excepción de Palmeira y Noia; en el primer puerto, a la uniforme declaración de que el «Diezmo se paga uno de cada diez ferrados de todos los frutos», se precisa que por tal razón satisfacía «cada lancha y Barco de tráfico cinco Reales y Medio». En cuanto a Noia, esta fuente fiscal hace constar que el párroco de San Martiño percibe enteramente «un medio quiñón... de las

${ }^{39}$ Archivo Parroquial de Santiago de A Proba do Deán. Libro $3^{\circ}$ de Fábrica (17971850). La Fábrica de Cangas deja de percivirlo en 1821 y no vuelve a ingresarlo tras el Trienio Liberal, al contrario de lo que sucedió en otras feligresías. Vid. RODRÍGUEZ FERREIRO, H.: Economía y sociedad..., p. 512, nota 837.

${ }^{40}$ Se documentan menciones esporádicas a cantidades irrelevantes «procedidas de el petitorio de pescado» o «de limosna de las dornas». Por ejemplo en Ribeira, en las cuentas de 1737 se registran 28 rs. «Que ynportaron los pulpos que se juntaron de limosna», cuando el cargo total asciende a 2.910 reales. En cuanto a Palmeira, entre los ingresos percibidos por la fábrica correspondientes a los años 1693-94 se especifican 24 rs. «de limosna de las dornas», siendo el total percibido de 275 reales. Vid. A.H.D.S. Fondo Parroquial de Santa Uxía de Ribeira. Administración Parroquial . Libro no 1 (ss. XVIIXVIII). Fol. 321 r.; Fondo Parroquial de San Pedro de Palmeira. Administración Parroquial. Libro n ${ }^{\circ} 1$ (1606-1707). Fol 53.

"CUADERNOS DE ESTUDiOS GALLEGOS", Tomo XLVI, Fascículo 111, Santiago 1999. 
traínas del gremio de la mar». Para el resto de las localidades barbanzanas los funcionarios de la Real Hacienda se limitan, al margen de anotar quienes son los preceptores de la carga, a constatar entre los productos sujetos a esta contribución, a la sardina y el pulpo, siendo el Coto de Martín la única población que entre sus frutos diezmales, además de estas dos últimas referidas especies, incluye el congrio ${ }^{41}$. Boiro, Corrubedo, Noal (O Son), Caramiñal y Abanqueiro, según las escuetas respuestas al referido interrogatorio no parecen contribuir en concepto de diezmo de mar, por el contrario en la villa de A Pobra do Deán en pago a tal contribución «cada fuego» del gremio de mareantes supuestamente tendría que aportar 5 reales, dineros de los que el cura percibiría 2/3 partes. Los rectores barbanzanos, según el Catastro, eran en la mayoría de los casos, los principales beneficiarios del diezmo; así, por ejemplo, los párrocos de Carreira y del Caramiñal los percibían «enteramente» ${ }^{42}$. Esto explica que las contabilidades parroquiales no permitan conocer el monto del diezmo de mar, su evolución y cuándo se iniciaría la caida sostenida en los ingresos por tal concepto. Lo que sí debemos constatar es que desde mediados del siglo XVIII existen indicios documentales para el Barbanza de una serie de pro-

${ }^{41}$ Vid. A.H.U.S. Catastro de Ensenada. Respuestas Generales de : San Pedro de Palmeira [Rollo microfilm 76. Libro 250. Fol 732 r.], villa de Noia [Rollo 78. Libro 253. Fol. 338-338 r.], San Pedro de Carreira [Rollo 76. Libro 250. Fols. 607r.-608], Coto Deán [Rollo 76. Libro 250. Fol. 671], Santa Uxía de Ribeira [Rollo 76. Libro 250. Fols. 535r.-536], Abanqueiro [Rollo 76. Libro 251. Fols. 107 r.-108], Coto de Martín [Rollo 78. Libro 253. Fols. 338-338r.], San Vicente de Noal [Rollo 76. Libro 251. Fols. 219220], Santa Baia de Boiro [Rollo 76. Libro 251. Fols. 170r.-171], Santa María de Corrubedo [Rollo 78. Libro 252. Fols. 629-629r.], villa del Caramiñal [Rollo 78. Libro 253. Fol. 404], villa de La Puebla del Deán [Rollo 78. Libro 253. Fol. 428], Santa Columba de Rianxo [Rollo 76. Libro 251. Fols. 420r.-421].

${ }^{42}$ Ibidem. En ese momento, la parroquia de A Pobra do Deán, registraría 71 marineros como cabezas de casa, si bien el número de fuegos bajo jefatura de gente del gremio de pescadores sería muy posiblemente superior, ya que se documentan viudas al frente de grupos domésticos integrados por hiernos e hijos matriculados. En cualquier caso, como mínimo, en razón de tal concepto tributario, se recaudaría 355 reales. Vid. A.R.G. Personal de Legos de Puebla del Deán. Sig. 2.284. En Palmeira, el diezmo general de todos los frutos ascendería en 1753 a 4.136 reales, percibidos a partes iguales entre el cura y la Dignidad Arzobispal de Santiago; de ese monto, 200 reales serían aportados en concepto de pulpo y 214 de los barcos de tráfico, que como es bien sabido conducían fundamentalmente sardina para beneficiar en Portugal. O sea, indirectamente se fiscalizaba el comercio de pescado. Véase, BRAVO CORES, D.: El Barbanza Meridional..., p. 87.

"CUADERNOS DE ESTUDIOS GALLEGOS", Tomo XLVI, Fascículo 111, Santiago 1999. 
blemas derivados del intento, por parte de sus preceptores de incrementar dicha carga o modificar las costumbres en su pago; ésta es la causa de los litigios aducida por la parte contribuyente. Para los beneficiarios del diezmo, los conflictos radicaban en la resistencia del gremio de mareantes -o cuanto menos de cierto número de matriculados- a satisfacer una carga del todo legítima.

Por un poder otorgado el 10-VIII-1763 por los cinco mayordomos y cabos celadores del gremio de mar de Ribeira, Coto de Martín y Coto del Deán -junto con 52 individuos de dicho colectivo- a dos procuradores «de las audiencias arzobispales y más de la ciudad de Santiago», se nos informa que dicho gremio se halla «con la extraña novedad» de que el cura de dicha feligresía había mandado convocar en el atrio, antes de la misa conventual, a los citados otorgantes y allí dicho rector y don Diego de Soto y Melchor Sánchez, escribano, «hiernos de doña Manuela Venavides [...] que es quien por sí, y otros llevan la çincura de la expresada feligresía, que es mitad enteramente de los diezmos de mar y tierra, y más Abinsas que produce dicho curato» expusieron, que los mareantes «les hubiesen de llamar así a dicho cura $\mathrm{y}$ çincureros todas las veces y quando quisiesen vender por menor, algunos pescados, así frescos como curados como eran congrio, Pulpo, sardina, y del Dinero que sacasen de la más pesca de secadas y Diezmo de sus tierras y otras imposturas ympropias a la posesión y costumbre [...] y es, de que [continúan declarando los otorgantes] para mantenérense y a sus pobres familias, quando se le proporsiona mercaderes que compren dichos jéneros así en la Mar, como en la tierra, ajustárselos y vendérselos en lo que puedan sacando de las Libras, Piezas, Quintales o ymporte de lo que produce cada expecie, lo correspondiente y christiano al Diezmo que acostumbran; con lo que quedan en su poder y después lo pagan a dicho cura y sincura, el congrio por el San Miguel, el pulpo por el Henero y el Ymporte del diezmo de sardina y más pesca de secada a los tiempos acostumbrados; y luego que se da aviso en la Yglesia de que se ha de yr a recojer por los unos y otros, por lo qual, siempre han estado y están mui prontos sin causarles ninguna omisión...» Los representantes del gremio de mar esgrimieron que ninguno de los párrocos anteriores al frente de su feligresía «ni los que antes obtuvieron dicha sincura (que ésta es) de la Ynsigne Colegiata de la ciudad de la Coruña» pretendieron semejante control sobre sus captu- 
$\operatorname{ras}^{43}$. No obstante, en la feligresía donde, al parecer, las tensiones por asuntos del diezmar estuvieron más a la orden del día, fue en el Xobre. Centremos nuestra atención en dos pleitos desencadenados en esta localidad, cuya existencia nos es conocida gracias a dos hatillos de papeles conservados en su archivo parroquial.

\section{LOS CONFLICTOS DIEZMALES EN SANTA MARÍA DEL XOBRE (1759-1806)}

El 20 de marzo de 1759 daba comienzo un pleito a raíz de la demanda presentada por el rector de Santa María del Xobre contra los matriculados de su parroquia por resistirse al pago del diezmo de la merluza. Estos alegaban que «anteriormente no havía en dicha feligresía marinero ni pescador alguno, y que sólo vinieran dos de afuera a residir allí»; además esgrimían que solamente solían contribuir con pulpo, ya que carecían de barcos y aparejos apropiados para capturar otras especies ${ }^{44}$. Prácticamente un año después, concretamente el 26 de marzo de 1760, el juez provisor y vicario general de la diócesis compostelana emitía una sentencia -no apelada por ninguna de las partes- que reconocía y amparaba el derecho del cura actual, don Fernando Cancela, y de sus sucesores al frente del beneficio curado del Xobre, a percibir el «Diezmo del pulpo seco, y del fresco que se vendiese y beneficiase y a los Demandados en la posesión y livertad de no pagar diezmo de los demás pescados, menos de la Merluza o pescada», la cual debía satisfacerse «en el modo, tiempo y quando se hace de los demás pescados Diezmales, entendiéndose sólo de la fresca que consumiesen en sus Casas, o de otra manera, sin perjuicio del derecho de propiedad a las partes». El 18 de agosto siguiente, se libraba carta ejecutoria a favor del referido párroco demandante. A continuación se

${ }^{43}$ A.H.U.S. Distrito de Noia. Rollo 369. Prot. $\mathrm{n}^{\circ} 1.890$, fols. 30-32.

${ }^{44}$ Dicha declaración no parece del toda ajustada a verdad si tenemos en cuenta la respuesta al interrogatorio con motivo del establecimiento del Montepío en 1777, según la cual en el puerto del Maño-Xobre nos encontraríamos con dornas que «en todo el año se emplean a la pesca con cordel de Pulpo, Fanecas, Besugos, algunos Abadejos y otros diferentes Pescados». Vid. A.C.S. Montepío para el fomento de la pesca en Galicia. Leg. 411. Fol. $50 \mathrm{r}$.

"CUADERNOS DE ESTUDIOS GALLEGOS", Tomo XLVI, Fascículo 111, Santiago 1999. 
intentó por parte de este último que los matriculados o sus consortes declarasen personalmente y bajo juramento qué cantidad de merluza y pulpo habían beneficiado en los años 1758 y 1759, pero tan sólo dos de ellos aceptaron tal requerimiento, debido a lo cual, se acudió al subdelegado de Marina del Caramiñal para que apremiase a los resistentes; nada se logró, pues este funcionario defendió a los pescadores. Así, el cura elevó recurso ante el Tribunal de Provisorato que nombró un asesor para que librase nuevos autos, decretándose el 22 de enero de 1763 la tasa del diezmo de pulpo y de la merluza beneficiados de 1759 a 1762. Esta «regulación líquida» del importe de las ventas de ambas especies, fue realizada por dos peritos, elegidos cada uno de ellos por los litigantes. Por lo que respecta al pulpo fresco se reguló el dinero obtenido por veinte contribuyentes, alcanzándose la cifra de 62 reales y medio, o sea, el beneficio de tal cefalópado había reportado a esta gente del gremio de mar 621 reales, si bien las ganancias por tal comercio variaban bastante; mientras Francisco Moares debía satisfacer 7 reales, a Sebastián Núñez «no le regularon cosa alguna». Por lo que respecta a la merluza, los peritos acreditaron que en 1758 diez matriculados habían vendido «en fresco y alguna curada» ciertas cantidades por un valor total de 50 reales, «y a cada uno de ellos por razón de diezmo les toca a medio real de vellón que deven pagar al citado cura». O sea, esta carga eclesiástica por excelencia, en la parroquia que nos ocupa equivalía exactamente a una décima parte del valor de las capturas $^{45}$

El 23 de febrero de 1763, 19 matriculados por sí y en nombre de los ausentes e impedidos de su misma condición se obligaban con sus personas y bienes a seguir pagando el diezmo del pescado «en la manera que lo hicieron hasta aquí; esto es, del pulpo curado por Natividades de cada año... pero con Condición que no lo puedan vender entonces ni antes sin primero avisar a dicho Cura para que asista a dicho Diezmar, y recoja lo que le corresponda, siendo de la obligación de los otorgantes traerlo a dicha Casa Rectoral, y lo mismo de la pescada Curada si se pescare en los mismos tiempos, y fuera de ellos, y por lo que mira al pulpo fresco y

${ }^{45} \mathrm{El}$ «executor» del Tribunal de Provisorato atendió la súplica de 3 matriculados que «mediante heran días de Entruexo [o sea, de carnestolendas] rogaban el retraso de su paga, la cual pasado el carnaval satisfacieron.

"CUADERNOS DE ESTUDIOS GALLEGOS", Tomo XLVI, Fascículo 111, Santiago 1999. 
merluza fresca que cogieren y vendieren en fresco, ha de ser obligación antes de venderlo ygualmente diezmarlo pagando al cura el contingente del mismo modo que queda advertido». Semejante escritura de allanamiento, pasada ante notario, al parecer pronto dejó de ser respetada ${ }^{46}$, llegándose a que en 1793, el entonces rector del Xobre, don Antonio Carlos Acero, denunciase ante el subdelegado del Caramiñal que tal obligación contraída «no lo executavan los más, y con expecialidad Domingo Gago y Manuel García, que clandestina y subrecticiamente ocultavan y veneficiavan su pesca» sin diezmar en modo alguno. Dicha queja provocó que el 15 de enero de 1793, 19 matriculados del Xobre otorgasen otra escritura de allanamiento en los mismos términos que la anterior de $1763^{47}$. Esta nueva especie de concordia duró bien poco.

\footnotetext{
${ }^{46}$ En un poder notarial de 1766 con motivo del citado pleito sobre diezmo de pescadas, se nos informa que «obtubo húltimamente el puerto y gremio sentenzia favorable y aora pretende el sobredicho [don Fernando Cancela] se le pague lo correspondiente a la merluza sin estar arreglado al tanto que deve ser, porque sólo este año se cojieron algunas por casualidad, y el cura no quiere arreglarse a la costumbre de otros puertos y jéneros de pesca...» El citado párroco «alcanzó despacho con que requirió a escrivano que les está apremiando» o sea, a los pescadores, a satisfacer dicha carga. Vid. A.H.U.S. Distrito de Noia. Rollo 455. Prot. no 2.402, fol. 83.

${ }^{47}$ Por la correspondencia mantenida entre el cura del Xobre y su patrono, el Marqués de Camarasa, señor de la jurisdicción de Xunqueiras a la que pertenecían, además de la referida parroquia, entre otras, las feligresías del Caramiñal y de Corrubedo, sabemos de los frecuentes envíos de pescados y mariscos -en su mayoría escabechados- que desde el Barbanza se destinaban a la capital de España para ser degustados por el citado señor y su familia. Estas fuentes no nos permiten conocer si tales especies marinas eran reclamadas a los vasallos de Xunqueiras en concepto de renta o si por el contrario eran compradas, lo más probable, por el rector al frente del beneficio eclesiástico para obsequiar a su amo; de obedecer a esto último, creemos que los mareantes no tendrían mayor inconveniente en vender sus piezas, habida cuenta que en la mayoría de las ocasiones se trataba de productos poco significativos en su alimentación cotidiana y destinados fundamentalmente al comercio local o de más alto radio. Así , por ejemplo, don Carlos Acero en carta remitida a su señor con fecha 11 de junio de 1793, informaba que «Después de algunas solicitudes en los puertos de este contorno, pude solamente, excelentísimo señor, juntar en dos rodaballos, que acompañados de media docena de merluzas suplico a vuesa excelencia con la maior sumisión se digne admitirlas por demonstración de mi reconocido afecto». Por aquel entonces, el litoral barbanzano sufría una importante crisis pesquera, carestía «qual nunca acuerdan los nacidos», incluso de sardinas «con que se mantengan los pobres» y que era atribuida «a los continuos nortes y con la falta de agua» [suponemos que Acero se refiera a la escasez de precipitaciones]; esta situación extrema condujo a que el citado cura elevase fervorosas súpli-
} 
El 7 de octubre de 1806 se iniciaba otro pleito que enfrentaba a las partes ya conocidas por igual causa. Dicho litigio «pendió» en la escribanía de la Comandancia de Marina de Villagarcía, y el desarrollo del mismo nos es conocido gracias a un «memorial ajustado» al expediente abierto por tal motivo ${ }^{48}$. Las pretensiones del rector, don Carlos Acero son las mismas que las que formulara trece años antes. En su defensa esgrimía la antiguedad en la percepción del diezmo, y su derecho avalado por la carta ejecutoria de 1763 y posteriores allanamientos de los matriculados de su parroquia. Por su parte, los demandados en sus diligencias afirmaban su condición de «Pobres marineros que con el producto de su pesca se mantenían y a sus mugeres y Familias contribuyendo con el diezmo de las tierras que travaxan y aun del Pulpo que pescan», pero en lo relativo al diezmo de la pescada rechazaban por de todo injusta la pretensión de Acero, pues la «gavela en dinero» sobre tal especie - a cuya pesca «solían dedicarse en algunas estaciones del año»-su antecesor al frente de la feligresía, don Domingo Rodal «en 22 años que fue Cura nunca se la havía cobrado», ni había osado reclamársela. En apoyo de su argumentación, estos matriculados aducían la existencia de 2 textos normativos que vetaban la percepción de ciertas contribuciones sobre la pesca. En concreto, se trataba del ya citado artículo $7^{\circ}$ del título V de las Ordenanzas de Matrículas de 1802, y de un Real Decreto de 1 de febrero de $1806^{49}$.

cas a San Antonio de Padua, advocación del convento franciscano inmediato a su parroquial. Nada había conseguido con sus súplicas, de ahí que estuviese «enojado con mi santo por esta desatención, maiormente porque conozco que quien pudo obligarlos peces a oir su doctrina, podría también hacer que se metiesen en las redes de los Pescadores de estas inmediaciones». Vid. A.H.U.S. Fondo Ducal de Medinaceli. Sección Amarante. Rollo de microfilm 567. Leg. 91. Docs. Xobre,11-VI-1793 y 14-VII-1793. Como vemos esta pésima coyuntura pesquera no fue óbice para que el cura del Xobre exigiese a rajatabla la satisfacción del diezmo de mar en ese año.

${ }^{48}$ Archivo Parroquial de Sta. $\mathrm{M}^{\mathrm{a}}$ del Xobre. Memorial ajustado del Pleito de Don Antonio Carlos Acero de Araujo... con Benito Fernández y Consortes, Marineros Matriculados sobre paga de Diezmo de Pulpo y Merluza. Año 1806. Sin foliar.

${ }^{49}$ Véase, nota 15 . La ley de 12 de agosto de 1802 concedía a los matriculados «amplia facultad para vender libremente el pescado en los muelles y Playas sin postura ni yntervención alguna de las Justicias o regimientos, a que se sujetarán en la forma prevenida sino prefirieren internar el pescado en los Pueblos para venderlo en ellos, no contrayendo esta obligación sino únicamente fueren de tránsito para conducirlo a otras Poblaciones; vien entendido que en todos los Pueblos en que huviese Gefe militar de 
Ambas soberanas resoluciones fueron compulsadas por el escribano de Marina de la Comandancia, y añadidas al expediente a petición del apoderado de los denunciados, quien alegaba que sus clientes satisfacían la carga de que venimos tratando «ygnorando quanto a este título o causa lexítima porqué se lo perciven, que sería y serấ ninguno siempre que se examinase su principio, por no haverlo más que de una de dos maneras, $o$ por sugestión de los Curas Párrocos o por mera condescendencia e ignorancia» de los contribuyentes ${ }^{50}$. En un auto posterior, el abogado de los matriculados -introduciendo en su razonamiento nuevas claves-, se preguntaba «vajo qué principios de sana moral, derecho Natural, civil y canónico, se puede sostener una carga que arruína a tantos vasallos para hazer rico a uno? Los Diezmos fueron constituídos para el alimento del Ministro del Altar, y por lo mismo no cave en razón que el Alimentante se quede Pobre para poner opulento al Alimentario... teniendo como tiene [el demandante] más de dos mil ducados anuales de Diezmos Prediales» ${ }^{51}$.

matrícula, deve intervenir en los precios que se pongan al pescado por las Justicias y Ayuntamientos». La letra de este artículo era conforme a las reales órdenes de $27-\mathrm{V}$ 1779 y posterior de 6-IX-1804. El otro texto esgrimido, el real decreto de 1-II-1806 había sido promulgado en atención a la queja del gremio de mar de Cádiz y abolía «el derecho que se cobra de 10 reales Vellón por cada Barco que entra con el pescado» en el puerto de la capital gaditana, disponiendo a su vez la aplicación escrupulosa del artículo de 1802 mencionado más arriba. Vid. A.P. de Sta. $\mathrm{M}^{\mathrm{a}}$ del Xobre. Memorial ajustado...

${ }^{50}$ Continuaba argumentando el defensor de los pescadores, que el demandante era conocedor de que «aunque los Diezmos son de derecho divino quanto a la Congrua, no lo son quanto ala Cota que ésta no está determinada, y puede serlo de diez uno, o de veinte uno o ninguno en donde no haya costumbre de pagarlos como no la hay en algunos Pueblos de Ytalia, siendo uniforme sentencia de todos los canonistas que siguen al Angélico Doctor Santo Thomás, que no puede percivirse diezmo de las cosas mínimas y de todos aquellas en que no haiga costumbre. Vid. Ibidem. En concreto esta última información se recoge en un auto mandado trasladar por el Auditor de Guerra de Marina de la Comandancia de Villagarcía el 20 de noviembre de 1806.

${ }^{51}$ Además dicho apoderado afirmaba que el «Diezmo de la Mar... apenas tiene nombre en Derecho: tal vez la Adversa [el rector del Xobre] le querrá llamar Diezmo personal, pero de esto resulta una desigualdad jamás iniqua que se puede imaginar, atendiendo a que en el Jobre no se paga Diezmo por la Yndustria. Nada pues diezman los Herreros, sastres, Carpinteros, ni de otro oficio y luego se ha de cargar a los Marineros que sacrifican sus vidas con desamparo de sus casas y familias y abandono de sus Yntereses en beneficio del Estado». Vid. A.P. de Sta. $\mathrm{M}^{\mathrm{a}}$ del Xobre. Memorial ajustado...

"CUADERNOS DE ESTUDIOS GALLEGOS", Tomo XLVI, Fascículo 111, Santiago 1999. 
Hasta aquí la argumentación de la parte demandada. Ahora, retomando el discurso del apoderado del cura litigante, éste recalcaba que el diezmo gravaba toda producción, si bien llegaba a reconocer que allí donde no hubiera costumbre de satisfacer tal carga eclesiástica «merecería desprecio la pretensión del que lo hiciese». Y dejaba bien claro que la mencionada carta ejecutoria de 1763, y los allanamientos antes citados, probaban inequívocamente que la reclamación de su cliente en modo alguno chocaba con lo dispuesto en las reales resoluciones que según los matriculados del Xobre amparaban su posición en este pleito. Además el abogado de Acero traía a colación que en feligresías barbanzanas como Carreira y Palmeira, como igualmente en otras del cercano litoral arousano, se estaba pagando el diezmo de mar según la costumbre. Sin embargo, el mismo letrado al referirse a litigios semejantes que se resolvieron favorablemente para los preceptores, da prueba de que la resistencia al pago del diezmo estaba bastante extendido por las costas gallegas, al menos por lo que a las Rías Bajas se refiere. Así, recordaba que el Capitán General del departamento de El Ferrol, luego del informe del auditor del mismo, había resuelto -con la aprobación del Director General de la Armada- que los matriculados del puerto de Vilagarcía de Arousa continuasen satisfaciendo «el uno por quince de la pesca que en razón de Diezmo exsigen el Cura Párroco y el Dueño de la Casa de Vista alegre» ${ }^{52}$. Además, investigaciones llevadas a cabo por la parte acusadora, echaban por tierra la

${ }^{52}$ También citaba otro pleito seguido en el Juzgado de Marina de la Comandancia de Vilagarcía por don Francisco Antonio Moas, párroco de San Xenxo de Bamio, y don Cayetano Blanco, rector de Santiago del Carril, con los matriculados Rafael y Pedro Franco, cuya sentencia obligó a estos últimos a pagar a ambos curas la quinceava parte de lo capturado «en sus redes y aparejos». Ibidem.

La cuantía del diezmo de mar ha sido cifrada entre un 1/14 y un 1/22 de las capturas de pescado. Véase, SANTOS CASTROVIEJO, S.: <<Transformacións e conflictos na sociedade galega da beiramar no século XVIII >>, en Grial, nº 67 (enero-marzo de 1980), p. 34 .

Más gravosa que esta media aparece la carga cobrada en el Xobre, ya que equivaldría -como se ha señalado más atrás- a una décima parte de los ingresos obtenidos del comercio de pulpo y pescada, igual proporción que la recaudada por tal concepto sobre el congrio y el mencionado cefalópodo («de 10 libras 1 o de cada diez reales 1") en la feligresía de San Julián de la Isla de Arousa. Vid. Archivo de San Payo de Ante-Altares. Fondo San Martín Pinario. Pleitos 18 B/ 9.

"CUADERNOS DE ESTUDIOS GALLEGOS", Tomo XLVI, Fascículo 111, Santiago 1999. 
supuesta pobreza de los demandados. Según estas pesquisas, en el Xobre se ejercitaban en la pesca de merluza 22 patrones, de los cuales 11 satisfacieron el diezmo de la pescada, y estos «son menos Pescadores que los diez [demandados] y aunque Domingo Gago [ya denunciado por semejante impago en 1793] hace como los que pagaron y coge menos pescadas por dedicarse al Pulpo, no obstante quiere probar dicho cura, por asentar el sobredicho no las veneficiara, que las ha cogido «, y así hizo incluir en su recurso que los familiares de este último matriculado habían vendido merluzas en las plazas del Caramiñal y de A Pobra do Deán, ya que «en el año próximo pasado hubo una cosecha mui abundante de Pescadas y dilatada por espacio de más de cinco meses». Por ejemplo, según el preceptor del diezmo, Benito Fernández, uno de los demandados, a la sazón cabo celador de su gremio «hubo noche que cogió más que quatro Docenas [de 26 unidades cada una]... y le han producido 332 rs. en la citada noche ${ }^{53}$. El apoderado de don Carlos Acero, presentaba recurso, ante el Juzgado de Marina de la Comandancia de Vilagarcía, contra los errores cometidos en la instrucción del sumario, ya que el escribano del citado tribunal, no había hecho constar las ganancias obtenidas por los matriculados denunciados en concepto de venta de merluza ${ }^{54}$. Y nada sabemos acerca de cómo finalizó este «juicio contencioso e interesante caso, como es el presente que excede de los seis mil reales»; la visita efectuada el 22-IX-1807 a la parroquial que nos ocupa, ni en ninguno de

${ }^{53}$ «Y a proporción hicieron lo mismo los demás denunciados «quienes a veces por no haver Compradores de dichas pescadas en los sitios acostumbrados las llevaban a veneficiar a Villanueba de Arosa, Rianjo y otras partes, de que han echo mayor partida de reales, que a juicio prudente en el referido año de ochocientos seis, excedió dicho Cabo y consortes de dos mil reales cada uno de Producción». Esta información aparece recogida en un folio encabezado como Advertencias del señor Abad del Jobre contradiciendo la relación presentada... por la parte demandada.

El cálculo de las ganancias por el apoderado del rector del Xobre quizás peque de hipervaloración, como es lógico, ya que a la pregunta 14 del interrogatorio de La Unica Contribución correspondiente a la vecina villa de Pobra do Deán, se responde que cada pescada curada se valora en 2 reales.Vid. A.H.U.S. Catastro de Ensenada. Respuestas Generales de la Villa de La Puebla del Deán. Rollo 78. Libro 253. Fol. 427 r.

${ }^{54}$ Este letrado, partidario del peritaje de los ingresos obtenidos del comercio de pescado, instaba a desplazarse a Padrón y Rianxo donde residían los compradores «que no quieren venir al auditorio del Jobre».

"CUADERNOS DE ESTUDIOS GALLEGOS", Tomo XLVI, Fascículo 111, Santiago 1999. 
los controles precedentes, menciona para nada los dos litigios que hemos estado viendo, cuando el diezmo de mar, si tomamos por cierta la declaración de los matriculados reportaría al cura 400 reales al año ${ }^{55}$. No es de extrañar que los curas del Xobre viesen amparados sus derechos por las justicias pertinentes. Los preceptores de dicho impuesto a lo largo de la costa gallega venían defendiendo los suyos, e incluso obtuvieron despachos favorables del Consejo de Guerra cuando injustamente habían sido privados de cobrar el diezmo de mar $^{56}$.

La resistencia al pago de dicho impuesto eclesiástico, iría incrementándose progresivamente por nuestro litoral, hasta el punto que la Intendencia ferrolana llegó a emitir dictámenes negando el derecho de ciertos preceptores de diezmos de mar $^{57}$; litigios por dicha causa llegaron incluso a crear problemas de competencia a nivel judicial. Así, con fecha 5-X1775, el Ministro de Marina de Pontevedra, don Gaspar Wauters y Horcasitas enviaba al subdelegado de Vigo copia de una resolución que S.M., a consulta del Consejo de Guerra, había adoptado y por la cual ordenaba que «en lo subcesivo escuse la Real Audiencia de este Reino la Provisión del auto ordinario contra los Matriculados y qualquiera yndividuo militar...» Dicho auto había sido expedido a instancia del cura de Sada y Fontán, «por querer exigir el diezmo de la Pesca de aquellos matricu-

${ }^{55}$ Dicha declaración, efectuada por el gremio de mar en junta plenaria, obedecía al informe requerido por el Capitan General de Marina del departamento de El Ferrol, con vistas a atajar gabelas injustas como las padecidas por los matriculados gaditanos. De ahí que el Comandante de Vilagarcía comunicase el 7 de mayo de 1807 al rector del Xobre su obligación de presentar en el plazo de 8 días «los títulos de pertenencia» que legitimasen su derecho a percivir el diezmo de mar. Vid. A.P. de Sta. M $^{\text {a }}$ del Xobre. Libros I, II y III de Fábrica (1660-1843).

${ }^{56}$ Así, en 1783 dicho organismo -oídos los alegatos del gremio de mar de Cillero y las declaraciones del cura de dicha feligresía, del cabildo de Mondoñedo y de «los conventos de los Picos», preceptores del diezmo de mar en tal puerto de la costa lucense«consultó que el Ministro de la Provincia no devió despojar a los Partícipes del Diezmo del Pescado en el Puerto de Cillero de la posesión en que estaban de percibirlo y que devía reintegrárselo en ella con el importe retenido» A.G.S. Secretaría de Marina, leg. 275; doc. 30-VIII-1783.

También el cenobio cisterciense de Sta. María la Real de Oia obtuvo dos autos ordinarios de la Audiencia de Galicia y de la Chancillería de Valladolid, que reconocian su derecho a percibir 6 rs. de cada barco del puerto de Bayona; a tal tributación se habían resistido los mareantes de la citada villa pontevedresa. Véase el apéndice documental.

"CUADERNOS DE ESTUDIOS GALLEGOS", Tomo XLVI, Fascículo 111, Santiago 1999. 
lados». Por la citada resolución se facultaba al Juzgado del Departamento de Marina para entender en «los casos que ocurran a las ordenanzas del exército y de la Armada», mientras en el Consejo de Guerra recaerían las competencias en apelaciones ${ }^{58}$. Pero habrá que esperar a fines del XVIII y sobre todo a principios del XIX para encontrarse con una sólida y extendida oposición a dicha contribución religiosa, un frente antidiezmal que encabezaron los salazoneros catalanes -amparados en sus intereses por la legislación reformista emanada de las Cortes de Cádiz ${ }^{59}$ - quienes esgrimieron, entre otros argumentos, para el impago de tal tributo, que sus fábricas no producían frutos naturales sino industriales ${ }^{60}$. Con tal ardid,

${ }^{57}$ Valga el ejemplo de la feligresía de Corujo, cuyo titular, en 1776 no pudo acreditar ante las autoridades de Marina documentos que certificasen sus privilegios al respecto. Vid. Santos Castroviejo, Santiago, <<Transformacións e conflictos... > op. cit., p. 34.

${ }^{58}$ Véase, Museo de Pontevedra. Archivo de mareantes. Sampedro 283.

${ }^{59}$ En la sesión de 24-VIII-1811, Vázquez Figueroa defenderá la abolición de tal tributo. Véase, Santos Castroviejo, S., <<Transformacións e conflictos...»>, pp.34-35. Cinco años antes, en 1806, a raíz de la intensificación de las voces críticas hacia el diezmo, Ferrol había acordado que no se pagase, excepto donde tuviere larga tradición o cuando los prediales no sustentasen al párroco. Vid. Nota 53.

${ }^{60}$ Un antecedente de semejante argumentación se encuentra entre los alegatos del catalán Juan Ricart en 1783, con motivo de la demanda judicial presentada contra él por el párroco de Santa Eulalia de Lubre (Ares). Vid. ALONSO ÁLVAREZ, L.: Industrialización y conflictos sociales en la Galicia del Antiguo Régimen, 1750-1830, Madrid, 1976, p. 129.

Especialmente «ruidoso» fue el litigio que enfrentó, entre 1814-1816, al colectivo de fomentadores instalados en la Isla de Arousa, con el párroco de San Julián y el convento de San Martín Pinario de Santiago, preceptores ambos del diezmo que se negaban a satisfacer los primeros. Ya en 1790 , el citado cenobio benedictino había presentado «querella de fuerza» contra estos transgresores, logrando que estos últimos reconociesen mediante escritura de «transación y concordia» el derecho que se habían resistido a contribuir; no obstante, los catalanes volvieron a «perturbar» al citado monasterio en 1801 . Los eclesiásticos afectados mostraban su estupor ante los razonamientos aducidos por los catalanes para el impago de la citada carga, como el de «que el mar es territorio libre, que si algún incauto lo paga [el diezmo] es un abuso», por considerar al Estado como la única autoridad con derecho a cobrar semejantes contribuciones, y al que ya financiaban con sus «personales arbitrios». La indignación de los preceptores era mayor si cabe al ver como los matriculados de la isla seguían contribuyendo por este concepto a pesar de que habían «decaído en fortuna y los Catalanes hayan absorvido toda la utilidad de la Pesca». Ibidem. pp. 131-134. Archivo de San Payo de Ante-Altares. Fondo San Martín Pinario. Pleitos 18B/9.

"CUADERNOS DE ESTUDIOS GALLEGOS", Tomo XLVI, Fascículo 111, Santiago 1999. 
descargaban la responsabilidad de dicha contribución sobre los pobres pescadores, quienes capturaban el producto de la salazón, unos mareantes que en su mayoría no eran sino simples asalariados de los fomentadores y que terminaron por secundar a estos capitalistas foráneos, no contribuyendo con una carga, que para los curas arosanos suponía fuente importantísima de ingresos, en particular en Carreira, donde-según información de la década de 1810 - «pocas veces le ha bajado el arriendo del diezmo del pulpo que saca a subasta, de 16.000 reales al año» ${ }^{61}$.

\section{CONCLUSIONES}

Brevemente, haciendo balance de los resultados de nuestro acercamiento a la fiscalidad sobre la pesca en primer lugar debe reseñarse la diversidad de cargas o derechos señoriales que de un modo u otro gravaban o controlaban el aprovechamiento y comercio de la productos animales del mar. También se ha hecho hincapié en lo extendido de ciertas contribuciones «voluntarias» para financiamiento del culto, recaudadas entre el colectivo de mareantes, unas limosnas -que en menor medida que las peñoras- revestían escasa relevancia en el cargo de las contabilidades parroquiales del Barbanza. Pero al margen de estos conceptos, cabe subrayar el gran peso específico del diezmo de mar entre las contribuciones satisfechas por los pescadores de la comarca que nos ocupa, una carga que reportaba pingües beneficios, sobre todo a los párrocos, sus principales preceptores. Esperemos que una próxima consulta de los documentos sobre «valoración de curatos» aporten más luz acerca de este tipo de ingresos. Asimismo hemos podido comprobar como el impago del diezmo nunca estuvo muy extendido entre los contribuyentes de cada parroquia; esta resistencia, hasta bien entrado el siglo XIX no fue secundada por la mayoría de los matriculados, estando abanderada, entre los naturales -al menos en el caso del Xobre-, por individuos con responsabilidades en la gestión de su gremio (cabos celadores, mayordomos...), los

${ }^{61}$ MEIJIDE PARDO, A.: Negociantes catalanes y sus fábricas de salazón en la Ría de Arosa (1780-1830), La Coruña, 1973, pp. 13-15.

"CUADERNOS DE ESTUDIOS GALLEGOS", Tomo XLVI, Fascículo 111, Santiago 1999. 
cuales a menudo vieron amparadas sus posicionamientos por las autoridades de la Matrícula. La postura catalana fue claramente ofensiva desde bien pronto, introduciendo en su ataque al diezmo nuevas argumentaciones; la arribada del laicismo y la penetración creciente de los presupuestos liberales abrieron un debate político sobre la legitimidad de esta carga que acabó por ser suprimida dentro del proceso general de desmantelamiento de los pilares económicas del Antiguo Régimen.

TABLA 1

Resumen del estado de la Matrícula de Mar en el Barbanza. Años 1758-59.

\begin{tabular}{lrc}
\hline LOCALIDADES & Marinería & Embarcaciones $^{\mathbf{1}}$ \\
\hline Noia & 141 & 20 \\
Barquiña & 5 & 3 \\
Son & 197 & 26 \\
Carreira & 122 & 51 \\
Ribeira & 114 & 36 \\
Coto del Deán & 70 & 16 \\
Palmeira & 244 & 75 \\
Caramiñal & 154 & 22 \\
Corrubedo & 92 & 18 \\
Coto Martín & 113 & 40 \\
Xobre & 41 & 17 \\
Pobra do Deán & 132 & 21 \\
Sta. Cruz de Lesón & 7 & 2 \\
Rianxo & 161 & 23 \\
San Isidro de Postmarcos & 20 & 6 \\
Cabo de Cruz & 111 & 22 \\
Abanqueiro & 36 & 4 \\
Aguieros y Comba & 55 & 3 \\
Sta. María de Leiro & 7 & 419 \\
\hline TOTALES & 1.731 & 14 \\
\hline
\end{tabular}

Fuente: A.G.S. Secretaría de Marina. Leg. 300. Doc. Esteiro, 18-II-1759

'El número de barcos de comercio, también contabilizados, se reduce a 23 , siendo registrados todos los demás como de «pesca y pasage».

Según esta fuente, marinería y embarcaciones barbanzanas alcanzan el $27,1 \%$ y el $32,2 \%$ respectivamente, de los totales para la provincia marítima de Pontevedra.

"CUADERnOS DE ESTUdIOS GALLEGOS", Tomo XLVI, Fascículo 111, Santiago 1999. 


\section{APÉNDICE DOCUMENTAL}

Noticia de los derechos que la gente de mar de varios Puertos de este reyno, paga por razón del Pescado que coge, o en expecie de él, a Señores eclesiásticos, Seculares, o regulares, o a seculares o de lo con que arrivan a los mismos Puertos aunque los ayan cogido fuera de los de su districto, con expresión de los motivos en que se funda, a saver.

Partido de la Coruña.

Camariñas. En este Puerto se percive por el Cura de él de cada Barco por razón de Diezmo del Congrio que se coge en todo el Berano, quatro reales de vellón, y dos quinones por el de la sardina en el Ymbierno

Cee. En este Puerto se paga por diezmo al Arcediano de Trastamara, dignidad de la Santa Yglesia de Santiago a quien pertenece el de los fructos, una Sardina de cada quince de las que coge la gente de mar, e igualmente de Sardas, y de todo el demás Pescado

Corcubión. En este Puerto paga el gremio de mar al Cura por razón de Diezmo, diez quiñones de la Sardina que coge en los cercos, y no haviéndolos, le da el mismo gremio 460 reales de vellón al año por el de todo el Pescado

Finisterre. La gente de mar de este Puerto paga al Cura de él por razón de Diezmo de cada quarenta pescadas que coge, una, y por consiguiente de Sardinas y Sardas.

Partido de Vigo.

Vigo. En este Puerto se cobra por la Justicia y regimiento de él, quatro mrs. de cada millar de sardina, y demás Pescados frescos y salados que entran y salen, y ocho mrs. de cada Cesta o Cestón de pescado grueso, por virtud de real Zédula de S.M. el señor Don Phelipo quinto de 19 de diziembre de 1703, para que sirva aquel ingreso a la composición de la Yglesia, Calles, fuentes y Calzadas, a causa de hallarse en aquel entonces uno y otro deteriorado procedido de las Ymbasiones que allí hizo el enemigo

Noia. En este Puerto se recauda por la Justicia y regimiento de él quatro mrs. de cada millar de Sardina consiguiente al Privilegio que S.M. se sirvió concederle el año pasado de 1737 para atender con su producto a los precisos reparos de la Yglesia Parrochial, Fuente y Puente.

Asimismo paga la gente de mar de dicho Puerto a la dignidad Arzobispal de Santiago por virtud de real Privilegio concedido en 4 de Agosto de

"CUADERNOS DE ESTUDIOS GALLEGOS", Tomo XLVI, Fascículo 111, Santiago 1999. 
1458 por S.M. el señor Don Henrique, un millar de sardina con el nombre de Cambo, cada Barco de la que coge.

Rianjo. En este Puerto, y los demás que comprehende esta Subdelegación, se paga por la gente de mar de ellos a los respectivos Curas el diezmo del Pescado que se coge.

Padrón. En este Puerto consiguiente a los Privilegios de los señores Reyes don Henrique y Don Fernando expedidos en 4 de Agosto de 1458, 8 de Abril y 15 de Diciembre de 1476 en que se ratifican los anteriores, se paga al Arzobispo de Santiago por los vecinos y gente de mar de dicho Puerto las rentas y demás que le corresponden, y le estavan concedidos antecedentemente, aunque se ignoran las que sean, y si sólo que con motivo de los nominados Pribilegios el mismo Arzovispo mandó se procediese a la averiguación y apeo de lo que las embarcaciones que allí, y en Puente Zesures entran está en costumbre de pagar, como depusieron varias personas y han visto cobrar por los Mayordomos del referido Arzobispo y Sugetos a cuyo cuidado estava, de cada Barco de dos puntas que entrava en el expresado Puerto de Puente Zesures, medio real de plata, y de los más pequeños de cada remo de él, dos Cornados; del Navío que trahía géneros, una pieza de cada uno en esta forma, de fierro un quintal, de Higos o Pasas un serón, de Azeite un arrova e igualmente de todo lo demás que conducía, y el Barco que llegava allí con pescado pagaba el Cambo de él siendo menudo, pero de las Pescadas una, y lo mismo de Pulpos y del Pescado que se llebava a Padrón se recaudava de cada cien piezas ocho, y no se save si esta exación continúa al presente, de que se tomarán verídicas noticias

Redondela. Este Puerto es un Señorío del Arzovispo de Santiago, y por lo mismo cobra de él las rentas, y demás que le están concedidas por privilegios anteriores confirmados por S.M. el señor Don Henrique en 2 de Febrero de 1467 y por dos Autos ordinarios del Tribunal de Galicia con motivo de reusar la gente de mar de él la paga de lo que antes hacían, se les mandó continuarla reduciéndose a dar cada Barco que andava a la sardina, un millar de ella y la dorna la mitad siendo desde Noviembre asta Henero, y no matándola en aquel tiempo, y andando a la pesca de otro género avía de pagar cada Barco quatro reales y la Dorna dos, y por cada carga de Sardina que se sacase por tierra fuera de aquel Puerto se devía exigir un maravedí, y siendo Pescado seco o frezco dos mrs. y medio y cada Barco un real

"CUADERNOS DE ESTUDIOS GALLEGOS", Tomo XLVI, Fascículo 111, Santiago 1999. 
Ysla de Arosa. En este Puerto paga el gremio de mar de él el Diezmo del Pescado que coge al Cura y al Priorato de San Martín de Santiago

Villamayor. En este Puerto se paga por la gente de mar de él las Alcavalas y cientos al Arzovispado de Santiago sin haverse exivido Privilegio ni otro Ynstrumento

Villa García. La gente de mar de este Puerto paga al marqués de Villa García las alcavalas y cientos de todo sin que por ahora conste de ningún Privilegio ni las cantidades que son

Fefiñanes. El Gremio de mar de este Puerto paga al Cura y sincurero de él por razón de Diezmo del Pescado que coge, de cada veinte piezas una

Cambados. En este Puerto sólo se paga por la gente de mar de él al Cura el Diezmo del Pescado que se coge

Portonovo. En este Puerto se paga el gremio de mar al Cura el Pescado que coge

San Jenjo. La gente de mar de este Puerto executa lo mismo que la partida antecedente

Bayona. En este Puerto según avisó el Subdelegado de él dice que cada Barco de él paga al Monasterio de Santa María la real de Hoya del orden de san Bernardo, seis reales de vellón anuales por la Pesca que hazen consiguiente al Privilegio concedido por S.M. el señor Don Alonso y después de algunos años se resistió la expresada gente a pagar los 6 reales y por dos autos ordinarios que se siguieron en la Audiencia de Galicia y Chancillería de Valladolid se mandó continuase la paga según lo habían hecho anteriormente, pero los Privilegios no se exivieron asta ahora

Partido de Puentedeume.

Ares. En este Puerto paga cada Yndividuo de mar al año al Cavildo de Santiago por razón de Diezmo 200 Sardinas, y las viudas que no tienen red 100, y por vasallage 14 y quartos cada uno, y las referidas viudas una Gallina de que no se exivieron Privilegios ni otro Ynstrumento

Partido de Rivadeo.

Rivadeo. En este Puerto avisó el Ministro se cobra por parte del Duque de Hijar como señor de aquel Condado, el derecho de Alcavala de todo el Pescado fresco y salado que se vende en la plaza, sin saberse lo que sea, ni manifestarse por su Mayordomo los Privilegios que aya para ello. 
Rinlo. En este Puerto se practica lo mismo que en el antecedente y por las propias razones. Ydem

Foz. En este Puerto paga la gente de mar cada año por razón de Diezmo al Cura dos reales por cada Barco

San Ziprián. El Gremio de Mar de este Puerto paga al Cura de él y al Cavildo de Mondoñedo un real de Diezmo por cada Quiñón

Burela. En este Puerto paga la gente de mar al Cura de él un real de cada quiñón, y un quarto en libra de Pescado curado que consumen en sus Casas, sin que para la percepción de esto último se aya manifestado Privilexio ni concesión real

Zillero. La gente de mar de este Puerto paga al Cura y sincureros de él el Diezmo del pescado que coge

Santa Marta. En este Puerto paga el gremio de mar medio diezmo al Cura del Pescado que coge

Cariño. Los Yndividuos de mar de este Puerto pagan cada año al Marqués de Astorga por razón de Señorío dos reales cada uno, sin que se hubiese exivido ningún Privilegio que lo haga constar

Espasante. En este Puerto paga la gente de mar lo mismo que contiene la partida antecedente, y por los propios motivos

Barquero. En este Puerto cobra el Cura y prestameros el Diezmo del Pescado que la gente de mar de él coge

Bares. En este Puerto se executa lo mismo que en el antecedente

Zedeyra. El Gremio de mar de este Puerto paga cada año a la Condesa de Lemus por razón de derecho de Pesca 370 reales de vellón en que antes de ahora lo aforaron, y en tiempo que avía en él 15 Lanchas de pesca, quatro Barcos que andavan al tráfico, y mucho trato, así de españoles como de estranjeros, y a causa de no haver al presente en dicho Puerto más que tres Lanchas que no tienen la gente suficiente, se halla esta vastante aflixida sobre la paga del expresado derecho, no haviéndose exivido por el Mayordomo de la misma Condesa, título ni Privilegio para hacer ver los motivos de la citada contribución.

Nota. Que los Ministros de Marina de los Partidos de Asturias y quatro villas asta ahora no han embiado noticia alguna de si en los Puertos de su comprehensión paga la gente de mar de ellos algunos derechos del Pescado que coge, y las que falten de demás de los Partidos de este Reyno así que pasen las respectivas se formará razón de las que sean.

Fuente: A.G.S. Secretaría de Marina. Leg. 281; doc. sin fecha. 